\title{
Post-suburbia dan Tantangan Pembangunan di Kawasan Pinggiran Metropolitan: Suatu Tinjauan Literatur
}

\section{Erie Sadewo, Ibnu Syabri dan Pradono}

Institut Teknologi Bandung, Indonesia

Email Koresponden: erie@itb.ac.id

Diterima: Januari 2018/Refisi: Januari 2018 Disetujui: September 2018

() 2018 Fakultas Geografi UGM dan Ikatan Geograf Indonesia (IGI)

\begin{abstract}
Post-suburbia merupakan fenomena transformasi perkotaan yang banyak ditemui di berbagai tempat. Fenomena ini terjadi sejalan dengan proses dekonsentrasi dan desentralisasi pekerjaan ke kawasan suburban yang menyusul populasi, sehingga menjadikan pusat kota kehilangan pengaruhnya. Tulisan ini dimaksudkan sebagai tinjauan terhadap berbagai literatur mengenai diskursus post-suburban dari sudut pandang filosofis. Selain itu, diberikan juga konteks perkembangannya di Indonesia, serta tantangan yang dihadapi oleh riset mengenai post-suburban kedepannya. Yaitu terkait dengan keberlanjutan perkotaan, apakah post-suburbia menghasilkan pembangunan yang tidak saja lebih ramah lingkungan, namun juga lebih baik secara ekonomi maupun sosial.
\end{abstract}

Kata kunci : post-suburbia, transformasi perkotaan, pembangunan berkelanjutan

Abstract Post-suburbia is a well spread urban transformation phenomenon which could be seen in many places. This phenomenon occurs along with the employment deconcentration and decentralization process following the population towards suburban area. Such process makes the urban core losing its influence. This paper aimed as a literature review of post-suburban discourse from a philosophical perspective. Moreover, we also discuss about its development in Indonesian context, and several possibilities of its research challenge in the future. Such as its relation with urban sustainability, whether post-suburbia would produce more not only environmental friendly development, but also in economic and social aspect.

Keywords: post-suburbia, urban transformation, sustainable development

\section{PENDAHULUAN}

Fenomena transformasi yang terjadi pada kawasan perkotaan sebenarnya bukan merupakan hal baru, melainkan merupakan suatu prosesyangbersifatgradual. Hari ini dunia tengah berada pada era posmodern yang berdampak pada hampir seluruh sendi kehidupan. Pada kawasan metropolitan, hal ini berdampak pada perubahan wajah perkotaan oleh proses spasial dan mengakibatkan perubahan menyeluruh pada struktur perkotaan (Helbich, 2012). Pada perkotaan modern, dorongan untuk tumbuh dan berubah bergerak keluar dari pusat kota ke kawasan disekitarnya. Namun pada era posmodern, logika tersebut seakan berbalik dengan semakin berkembangnya pusat-pusat perkotaan baru di kawasan pinggiran metropolitan (Dear \& Dahmann, 2008). Hasilnya berupa suatu tampilan yang berbeda dari apa yang sebelumnya dikenali sebagai suburbia, namun dideskripsikan sebagai bukan urban maupun suburban (Zukin, 1991 dalam Bontje, 2004).

Perubahan dalam masyarakat, ekonomi, politik dan budaya telah menghasilkan suatu struktur baru yang sangat berbeda dengan kota peristirahatan yang kita kenal pada era suburbanisasi klasik (Borsdorf, 2004). Terdapat dugaan bahwa proses urbanisasi tengah memasuki suatu fase baru yang bentuknya sama sekali berbeda dengan fase suburbanisasi konvensional yang kita ketahui. Bentuk suburbanisasi baru ini mendukung pembangunan stuktur polisentris perkotaan dan bangkitnya proses serta bentuk mosaik perkotaan posmodern (Soja, 2000). Sebagian besar penelitian tersebut diawali di Amerika Serikat, dimana suburban telah menjadi bagian penting dalam ruang perkotaaan Amerika sejak abad 19. Teori mengenai post-suburban pada mulanya berangkat dari pengamatan terhadap perubahan bentuk spasial yang terjadi di Los Angeles pada periode 1920-1930an dan kemudian berkembang pada kawasan metropolitan lainnya pasca Perang Dunia II (Kling, Olin, \& Poster, 1995b). Fenomena tersebut menjadi penting untuk dipelajari karena transformasi yang terjadi di Orange County berjalan pararel dengan pembangunan setidaknya 20 metropolitan lainnya di Amerika Serikat.

Fenomena post-suburban telah teridentifikasi di banyak tempat dengan berbagai bentuknya, tidak terkecuali di Indonesia. Pada masa yang akan datang dimana urbanisasi terus berkembang di kawasan pinggiran metropolitan, maka keberadaan postsuburban ini akan menjadi semakin strategis. Untuk itu, diperlukan adanya pemahaman yang lebih mendalam terhadap munculnya fenomena ini. Tulisan ini merupakan tinjauan terhadap berbagai literatur state of the art yang menyoroti tentang keberadaan fenomena post-suburbia dengan menggunakan pendekatan filosofis. Tulisan ini dibagi menjadi menjadi enam 
bagian. Pada bagian pertama merupakan pendahuluan yang menjelaskan pentingnya fenomena post-suburban, yaitu bagaimana pengertian serta karakteristik yang dimilikinya. Bagian kedua mengulas tentang ontologi fenomena post-suburban, dari segi pengertian serta karakteristik yang dimilikinya. Bagian ketiga mengulas mengenai epistimologi post-suburban, yaitu bagaimana fenomena tersebut dapat muncul dan menjadi hal yang banyak ditemui. Bagian keempat mengulas tentang aksiologi post-suburban, yaitu mengapa fenomena ini menjadi penting untuk dipelajari lebih lanjut. Bagian kelima merupakan ulasan mengenai kemunculan fenomena ini di Indonesia. Pada bagian terakhir akan dipaparkan beberapa kritik serta tantangan yang terkait dengan pembangunan di kawasan pinggiran metropolitan.

\section{POST-SUBURBIA SEBAGAI FENOMENA}

Secara ontologi, terdapat perbedaan cara pandang terhadap transformasi perkotaan yang terjadi di kawasan pinggiran metropolitan. Kling et al. (1995b) berpendapat bahwa setidaknya terdapat dua perspektif dalam memahami perubahan tersebut, yaitu pendekatan core-periphery yang terfokus kepada kota sebagai inti dan suburban sebagai kawasan suburban dan interkasi antara keduanya, serta pendekatan multipusat. Pendekatan pertama menghasilkan beberapa istilah seperti "outer city", "new city", and "satellite sprawl". Sementara cara pandang yang bersifat multipusat kemudian melahirkan istilah seperti "technoburbs", "urban villages", "middle landscape", serta "edge cities". Tradisi keilmuan yang lebih terbuka disebut telah menjadikan pendekatan multipusat sebagai perpektif yang lebih tepat dalam dalam memahami kehidupan di suburban. Kling et al (1995b) yang terinspirasi oleh pendekatan multipusat memberikan istilah postsuburban kepada fenomena tersebut. Proses yang mengendalikan struktur spasial baru tersebut dikenal sebagai post-suburbanisasi, sementara struktur spasial baru yang dihasilkan disebut sebagai post-suburbia (Helbich, 2012).

Meskipun istilah seperti 'edge city', 'edgeless city', atau 'technoburb' kemudian dinilai sebagai bagian atau ciri khusus yang secara bersama sama membentuk kesatuan gambaran post-suburbia (Wu \& Phelps, 2008), namun post-suburbia memiliki perbedaan yang substansial. Kling et al. (1995a) berargumen bahwa konsep "edge city" dianggap kurang peka terhadap kompleksitas ekologi sosial region post-suburban, serta tidak mempertimbangkan interaksi yang hadir didalamnya. Akibatnya, konsep tersebut kehilangan dasar desentralisasi serta karakter interkatif yang menjadikan region post-suburban begitu kompleks, inkoheren, dan dinamis. Dibandingkan dengan edge city, di region post-suburban berkembang pandangan kosmopolitan yang ramah terhadap pendatang, serta benar-benar meniadakan pemisahan terhadap pola permukiman dan pekerjaan. Konsep post-suburban secara substansial dianggap telah bertransformasi menuju arah yang semakin global.

Kling et al. (1995a) menjelaskan post-suburban dalam konteks Amerika Utara sebagai fenomena dimana suatu region memiliki beberapa pusat kegiatan yang saling berbeda dan terpisah satu sama lain. Perbedaan antar pusat kegiatan tersebut dapat diartikan bahwa dibandingkan bentuk terintegrasi antara pusat perbelanjaan atau kompleks industri dengan permukiman, post-suburban lebih lebih menunjukkan adanya lokasi spesifik untuk pusat permukiman, perbelanjaan, dan kompleks industri. Masing-masing pusat tersebut memiliki kekhasan yang dapat menyediakan beragam daya tarik. Keterpisahan antar pusat tersebut ditunjukkan dengan adanya spesialisasi fungsi kegiatan dan berlokasi dalam waktu tempuh 15-30 menit perjalanan antara satu sama lain menggunakan mobil. Frekuensi penggunaan mobil untuk bekerja, bersosialisasi, dan berbelanja dengan lokasi yang melintasi batas kota, cenderung seimbang dengan perjalanan di dalam kota. Pada kesempatan lain Lucy dan Phillips (1997) menjelaskan bahwa post-suburbanisasi merupakan suatu era baru dimana banyak suburban kehilangan populasi, penurunan pendapatan penduduk secara relatif dibandingkan situasi regional, dan wilayah exurban perdesaan yang jauh dari suburban yang telah berkembang mengalami pertumbuhan secara pesat.

Kling et al. (1995b) berargumen bahwa postsuburban memiliki beberapa karakteristik yaitu: Pertama, terintegrasi pada sistem pasar kapitalis global. Kedua, bertransformasi dari kawasan pertanian menjadi masyarakat yang didominasi oleh pekerja industi dan pasca industri dalam waktu yang relatif singkat. Ketiga, memiliki fase pembangunan: jaringan kota desa dalam kawasan perdesaan; kawasan suburban; bauran kawasan yang kompleks dan terdesentralisasi antara urban, suburban dan perdesaan. Keempat, memiliki bauran lingkungan kelas atas dan kelas bawah. Sebagai akibatnya, Fishman (1987) berargumen bahwa secara spasial formasi post-suburban akan memiliki beberapa ciri. Pertama, post-suburban merupakan kawasan pinggiran yang luas dan tumbuh sebagai unit ekonomi dan sosial yang bergairah. Kedua, terdapat pusat perbelanjaan, kompleks industri, kompleks perkantoran, rumah sakit, sekolah, serta berbagai tipe perumahan yang tersebar sepanjang koridor jalan raya. Ketiga, penduduknya mencari pekerjaan serta kebutuhan sehari-hari di sekitarnya dibandingkan harus menuju ke kota. Keempat, industri dapat menemukan pekerja serat berbagai jasa lainnya yang dibutuhkan. Kling et al. (1995b) menambahkan dua ciri formasi spasial post-suburban yaitu bentuknya lebih terorganisir pada beberapa distrik atau pusat yang memiliki spesialisasi dibandingkan dengan suatu pusat kota tradisional yang dikelilingi kawasan industri dan permukiman dan lebih dimungkinkan untuk memiliki pusat kebudayaan maupun komersialnya sendiri. 
Dalam konteks Eropa, (Bontje, 2004) mendeskripsikan post-suburbia sebagai konsentrasi multifungsional baru di kawasan sekeliling kota yang semula dikenal sebagai "suburbia". Sementara itu, (Borsdorf, 2004) mendeskripsikan post-suburbia sebagai suatu elemen baru dalam sistem kota-desa yang dicirikan dengan keberadaan berbagai unsur, yaitu:

a. Lokasi tempat tinggal yang memiliki daya tarik;

b. Infrastruktur baru dalam perdagangan dan jasa;

c. Kesempatan kerja yang menarik terutama pada sektor tersier (perdagangan, jasa, perkantoran, dan hiburan), serta industri (kompleks industri dan bisnis);

d. Gaya hidup masyarakat yang tidak dapat dikategorikan sebagai perkotaan maupun perdesaan;

e. Tingginya tingkat mobilitas perorangan;

f. Tingginya dinamika ekonomi spasial.

Dalam konteks global, Wu dan Phelps (2008) mendeskripsikan post-suburbia sebagai suatu fase baru yang berbeda secara kuantitatif dengan suburbanisasi konvensional. Fase tersebut ditandai oleh munculnya berbagai lokasi baru berbasis permukiman pekerja yang dominan di sekeliling pusat kota lama atau yang telah maju. Lokasi tersebut memiliki derajat kebebasan yang relatif besar terhadap kota yang dikelilinginya. Dalam hal politik, post-suburbia menggambarkan fragmentasi spasial tingkat tinggi dimana tidak terdapat satu pemerintahan yang mengatur seluruh lokasi tersebut, sehingga terjadi kompetisi yang diakibatkan oleh kekuasaan yurisdiksi yang saling terpisah. Sehingga meskipun terdapat perbedaan akibat adanya konteks lokasi, namun secara umum post-suburbia dianggap akan memiliki gambaran sebagai berikut:

a. Suatu kondisi yang terlepas dari proses suburbanisasi, terutama akibat pembangunan permukiman;

b. Memiliki karakteristik penggunaan lahan dan elemen morfologi perkotaan campuran didalamnya;

c. Pada lanskap perkotaan yang kompleks, dinamika pembangunan perkotaan sangat sulit untuk terlihat. Pembangunan tidak terbatasi oleh batas wilayah adminsitrasi yang ada;

d. Pada aspektertentu, pemerintah daerah memainkan peranan 'entrepreneurial' penting dalam pembangunan post-suburbia. Melalui peranan tersebut, pemerintah dapat mewujudkan nilai-nilai sosial kosmopolitan yang berbeda dibandingkan dengan yang terdapat pada suburbia;

e. Post-suburbia memiliki keseimbangan lokasi kerja dan tempat tinggal yang lebih besar dibandingkan dengan suburbia;

f. Bentuk post-suburban dikaitkan dengan penggunaan lahan yangluas dan saling bertentangan antara perumahan, industri manufaktur dan jasa, lahan terbuka, pertanian, dan taman. Hal ini juga disebut McGee (1991) sebagai ciri dari perluasan kawasan metropolitan di Asia Tenggara.

Pada kesempatan lain, Hudalah dan Firman (2012) yang juga berbicara mengenai konteks post-suburbia secara global, memberikan beberapa gambaran mengenai elemen yang dimilikinya seperti:

a. Suatu bentuk spasial baru yang berlokasi antara kota lama dengan perdesaan serta memiliki kehidupan, daya tarik dan dinamika yang serupa dengan perkotaan.

b. Memiliki sebagian besar karakteristik perkotaan, namun tidak multifungsional sebagaimana pusat kota lama. Terdiri atas bentuk spasial perkotaan yang berkepadatan rendah, terpisah secara sturktur, memiliki kekhususan dalam segi ekonomi, dan tersegregasi secara sosial (Borsdorf, 2004);

c. Pergerakan penduduknya tidak mengikuti pola kosentris atau radial yang biasa ditemui di kawasan metropolitan monosentris. Pola spasial yang dihasilkan cenderung bersifat polisentris, dimana suburban memiliki kebebasan lebih besar dan pemusatan aktivitas di pusat kota lama mengalami perlemahan;

d. Memilikigayahidupyang cenderungliberal, dimana institusi pemerintah, baik pusat maupun daerah kurang terlihat fungsi dan peranannya sebagaimana dapat ditemui di perkotaan tradisional.

Phelps et al. (2010) serta Wu dan Phelps (2008) berpendapat bahwa di negara berkembang, postsuburbia memiliki perbedaan yang substansial dengan fenomena suburban tradisional dalam hal:

a. Suburban kehilangan populasi, dan pendapatan rumah tangga menurun dibandingkan dengan pendapatan regional;

b. Pekerjaan di bidang jasa terdesentralisasi keluar dari pusat perkotaan; dan

c. Memiliki pola penggunaan lahan campuran dengan pilihan pembangunan polisentris.

Dapat disimpulkan bahwa meskipun konsep dan teori mengenai perubahan spasial yang dikaitkan dengan post-suburbanisasi telah mapan, namun masih terdapat kekurangan. Pertama, belum terdapat ukuran yang pasti mengenai karakteristik post-suburban. Helbich dan Leitner (2009) berargumen bahwa sebagai suatu pengetahuan mengenai pembangunan spasial, teori suburban dan post-suburban masih belum sempurna dan cenderung memiliki sifat fuzzy. Sedangkan Wu dan Phelps (2011a) justru mendorong agar konsep post-suburban tidak dilihat sebagai suatu definisi yang tunggal, melainkan sebagai suatu sinyal mengenai variasi proses serta potensi perubahan yang terjadi di kawasan pinggiran metropolitan. Dengan demikian, post-suburbia tidak hanya menjadi fenomena yang terjadi di negara maju saja, melainkan juga di negaranegara berkembang meskipun dalam bentuk yang 
berbeda terlepas dari latar belakang politik serta sejarah pertumbuhan perkotaaan yang dimilikinya. Kedua, masih kurangnya bukti empiris mengenai keberadaan post-suburbia dalam skala metropolitan (Helbich, 2012; Keseru, 2013). Selama ini riset mengenai postsuburbanisasi masih terbatas pada lokasi-lokasi tertentu dari metropolitan, misalnya Orange County di Los Angeles (Kling et al., 1995b), Khimki di Moskow (Golubchikov, Phelps, \& Makhrova, 2010), atau Cikarang di Jabodetabek (Hudalah \& Firman, 2012). Masih terdapat ruang yang cukup luas untuk penelitian lebih lanjut mengenai post-suburbia, terutama dalam skala metropolitan.

\section{MENUJU POST-SUBURBIA}

Epistimologi terbentuknya post-suburban tidak dapat dilepaskan dari proses suburbanisasi. Keseru (2013) berargumen bahwa teori suburbanisasi terbagi kedalam dua kelompok, yaitu yang berfokus pada proses suburbanisasi sebagai tahapan dalam urbanisasi, dan yang berfokus kepada hasil. Di negara maju suburbanisasi ditandai dengan pembangunan permukiman di luar perkotaan, redistribusi populasi dan desentralisasi aktivitas ekonomi (Firman \& Fahmi, 2017). Suburban memiliki karakteristik dan definisi yang sangat kompleks serta bervariasi antar negara. Tidak terdapat kesepakatan mengenai bagaimana suburban dapat didefinisikan, namun secara umum terdapat beberapa dimensi yang memiliki kesamaan. Menurut Harris dan Larkham (1999) dimensi tersebut antara lain: lokasi pinggiran terhadap pusat perkotaan yang dominan; sebagian atau keseluruhan karakteristik permukiman; densitas yang rendah, diasosiasikan dengan pola terdesentralisasi dan tingginya tingkat kepemilikan; Budaya, atau cara hidup yang berbeda;
Identitas komunitas yang terpisah, seringkali dilembagakan dalam pemerintahan lokal.

Aktivitas urbanisasi menyebabkan pola dan struktur ruang perkotaan bertransformasi menjadi semakin kompleks. Lang et al. (2006) menunjukkan bahwa dalam konteks Amerika Serikat, kawasan suburban sejak pertengahan abad 19 hingga saat ini, setidaknya telah mengalami enam tahap transfromasi yaitu: proto-suburbs, town and country suburbs, streetcar suburbs, mid-century suburbs, new metropolis suburbs, dan megapolitan suburbs. Akibat pengaruh globalisasi dan pergeseran industri menuju ekonomi post-fordist berbasis jasa, kawasan perkotaan di negara maju tengah memasuki suatu fase pembangunan yang baru. Restrukturisasi distribusi spasial dari lokasi produksi dan pasar tenaga kerja telah menghasilkan desentralisasi pekerjaan di perkotaan (Knox \& Pinch, 2009, dalam Keseru, 2013). Setelah beberapa selang waktu, fasilitas industri dan pekerjaan yang terkait mengikuti lokasi penduduk yang tinggal di sekitar perkotaan dan membentuk suatu rangkaian spasial baru di pinggiran kota (Glaeser \& Kahn, 2004).

Pada perjalanannya, para ahli bersepakat bahwa pada sebagian besar kawasan metropolitan, keberadaan "suburbia" yaitu istilah yang merujuk kepada lokasi suburban kota, saat ini semakin sulit untuk dapat ditemukan. Bentang alam yang terdapat antara kota dan perdesaan telah mengalami perubahan fundamental selama beberapa dekade terakhir, dimana bentukbentuk kawasan tradisional antara desa dan perkotaan tidak lagi eksis (Borsdorf, 2004; Tabel 1)). Bontje (2004) berpendapat bahwa suburbia mengalami perubahan secara bertahap menjadi lokasi yang semakin terpisah dari pusat kota tradisional. Lokasi permukiman yang semula memiliki kepadatan rendah semakin berbaur

Tabel 1. Perbandingan Karakteristik Suburbia dan Post-suburbia

\begin{tabular}{|c|c|c|}
\hline Karakteristik & Suburbia & Post-suburbia \\
\hline Dorongan & Pertumbuhan demografi, urban sprawl; & Meningkatnya imigrasi, Mobilitas individual; \\
\hline Kondisi & $\begin{array}{l}\text { Permintaan perumahan dan } \\
\text { pembangunan industri tinggi, tingkat } \\
\text { harga rendah, dapat diakses oleh } \\
\text { transportasi publik; }\end{array}$ & $\begin{array}{l}\text { Transformasi, globalisasi, perubahan sosial, } \\
\text { keragaman gaya hidup, segregasi, polarisasi, } \\
\text { fleksibilitas mobilitas pasca fordism, motorisasi; }\end{array}$ \\
\hline Gambaran & Bebas polusi, lebih alami; & Gaya hidup posmodern, orientasi kesenangan; \\
\hline Infrastruktur & $\begin{array}{l}\text { Hanya terdapat infrastruktur dasar, } \\
\text { kesempatan kerja rendah; }\end{array}$ & $\begin{array}{l}\text { Infrastruktur khusus, kesempatan kerja, } \\
\text { perdagangan; }\end{array}$ \\
\hline $\begin{array}{l}\text { Bentuk dan } \\
\text { Struktur }\end{array}$ & $\begin{array}{l}\text { Arsitektur homogen, kawasan hijau } \\
\text { besar; }\end{array}$ & $\begin{array}{l}\text { Arsitektur dan kawasan hijau yang beragam namun } \\
\text { meniru tempat lain; }\end{array}$ \\
\hline Aktor & $\begin{array}{l}\text { Kelas bawah dan menengah, keluarga } \\
\text { muda; }\end{array}$ & $\begin{array}{l}\text { Semua kelas, investor, pebisnis, pengembang, } \\
\text { olahragawan; }\end{array}$ \\
\hline Hasil & $\begin{array}{l}\text { Gedung beton, kota dormitori, jendela } \\
\text { hijau, dan monoton; }\end{array}$ & $\begin{array}{l}\text { Fragmentasi sosioekonomi dan spasial, } \\
\text { multifungsi, transformasi ruang pertanian, } \\
\text { menurunnya pemusatan lokasi; }\end{array}$ \\
\hline Fungsi & Menunjang pusat kota; & $\begin{array}{l}\text { Kawasan independen, bukan perkotaan maupun } \\
\text { pedesaan; }\end{array}$ \\
\hline
\end{tabular}


dengan permukiman padat penduduk, lapangan pekerjaan, lokasi pertokoan serta berbagai fasilitas rekreasi. Perubahn ini menghasilkan bentuk baru yang lain daripada yang pernah diketahui sebelumnya.

Dalam konteks perkembangan permukiman Phelps dan Wu (2011b) membagi transformasi perkotaan kedalam tiga tahapan. Tahap pertama dikenal sebagai kotamodern, yaitudimanakotabertransformasimenjadi suburban. Pada tahap kedua, kota bertransformasi menjadi suburban kemudian berubah menjadi postsuburban. Tahap ini dikenal sebagai region kota modern terbaru. Pada Jenis ketiga yang dikenal sebagai region kota yang mengalami modernitas kedua, terdapat lima kemungkinan bentuk transformasi yang berbeda yaitu: (1) dari post-suburban berkembang kota; (2) suburban yang berkembang, tumbuh menjadi post-suburban kemudian menjadi kota; (3) suburban yang makmur dan stabil bertahan sebagai suburban yang makmur dan stabil; (4) suburban mengecil menjadi sub suburban; dan (5) kota menjadi suburban. Tahapan tersebut menunjukkan bahwa proses post-suburbanisasi selalu dimulai dari adanya suburbanisasi dan akan memiliki perkembangan yang berbeda antar lokasi.

Pergeseran dari suburbia menuju post-suburbia pada negara maju, salah satunya dipicu oleh revolusi teknologi yang dimulai pada awal abad 20. Fishman (1987) menjelaskan bahwa pembangunan pasca perang dunia di Amerika menunjukkan terjadinya pergeseran lokasi perumahan dan industri secara simultan menuju pinggiran metropolitan. Berkembangnya tenologi mobil membuat orang dapat bepergian dari satu sudut metropolis ke sudut lainnya secara reguler setiap hari. Kemajuan di bidang telekomunikasi dan teknologi komputer memiliki potensi untuk menggantikan kebutuhan bertatap muka secara langsung serta pergerakan secara fisik lainnya. Hal ini menjadikan desentralisasi pekerjaan semakin dimungkinkan sehingga kawasan suburban Amerika secara berangsur mulai kehilangan keterikatan terhadap pusat kota yang telah mapan (Hudalah \& Firman, 2012). Desentralisasi berkelanjutan terjadi pada kota-kota besar di US seperti Portland, Oregon, and Philadelphia, Pennsylvania. Namun pada kota-kota tersebut, transisi dari struktur monosentris menjadi polisentris dan menuju ke arah menyebar tidak terjadi secara linier, namun memiliki perbedaan yang bersifat lokal Lee (2007).

Di kawasan Eropa, Bontje (2004) berargumen bahwa proses dekonsentrasi di Belanda pada tahap awal memang didahului oleh suburbanisasi populasi. Meskipun terdapat beberapa cabang usaha yang berpindah ke batas kota untuk memperluas ruang gerak dan mendapatkan aksesibilitas yang lebih baik, namun sebagian besar pekerjaan tetap terkonsentrasi di pusat kota. Namun kebijakan perencanaan spasial di Belanda memberikan inisiatif tinggal di pinggiran perkotaan (Borsdorf, 2004). Sejak terjadinya krisis manufaktur pada periode 1970 dan 1980an serta pergeseran dari struktur perekonomian berorientasi manufaktur menuju jasa, pertumbuhan pekerjaan di luar perkotaan telah meningkat sementara pertumbuhan ekonomi perkotaan cenderung tertinggal. Burdack (2002) berpendapat bahwa pembangunan kawasan pinggiran metropolitan di Eropa memiliki perbedaan dengan Amerika Utara. Argumen ini didasarkan pada posisi inti perkotaan di Eropa yang tetap menjadi pusat dominan dibandingkan dengan Amerika. Selain itu, pembangunan jaringan transportasi publik yang baik dapat memberikan alternatif bagi penggunaan mobil untuk melakukan komuter pada koridor utama.

Adanya upaya revitalisasi pusat kota dan kawasan produktif menjadikan perkotaan di Eropa tetap atraktif dan mampu mendorong urbanisasi. Helbich dan Leitner (2009) dalam penelitiannya di Vienna Austria menunjukkan bahwa determinan dari suburban termasuk faktor lokasi, seperti aksesibilitas yang baik serta harga lahan yang tinggi memainkan peran yang sangat penting dalam proses urbanisasi. Berbeda dengan Borsdorf (2004), Helbich dan Leitner (2009) menggunakan beberapa set keanggotaan fuzzy yang bersifat kuantitatif untuk membedakan karakteristik suburban dan post-suburban (Tabel 2). Hubungan antara tingkat migrasi masuk yang tinggi dengan aksesibilitas yang baik dan harga lahan menunjukkan adanya variabilitas spasial yang tinggi. Meskipun dari segi migrasi kota ke desa tidak terdapat bukti bahwa metropolitan Vienna telah mengalami transisi dari suburbia menjadi post-suburbia, namun seiring dengan meningkatnya populasi, kawasan pinggiran perkotaan diperkirakan akan mengalami proses restrukturisasi spasial besar-besaran yang dapat mendorong transisi menuju situasi post-suburban.

Pada konteks Asia, Wu dan Phelps (2008) mengidentifikasi bahwa terdapat tiga tahap dalam suburbanisasi. Pertama, terjadi suburbanisasi permukiman yang dipicu oleh pengembang swasta. Kedua terjadi proses suburbanisasi industri yang dihasilkan oleh kebijakan pemerintah pusat. Ketiga, suburbanisasi bisnis retail, yaitu berbagai pusat perbelanjaanberpindahkesuburbanuntukmendapatkan tanah yang luas dengan harga yang lebih rendah. Tahap pertama dan ketiga memiliki kesamaan dengan apa yang terjadi di Amerika Serikat. Proses pembangunan perkotaan di negara pasca sosialis bisa jadi merupakan mutasi dari mesin pertumbuhan ala Amerika. Namun ketika dilakukan perbandingan terhadap proses pembangunan yang terkait dengan politik lokasi maka terdapat perbedaan besar yang muncul (Golubchikov et al., 2010). Besarnya kewenangan yang dimiliki oleh pemerintah pusat memungkinkan adanya kontrol yang lebih ketat terhadap proses dekonsentrasi pekerjaan keluar dari pusat perkotaan. 
Tabel 2. Perbandingan Karakteristik Fuzzy Suburbia dan Post-suburbia

Suburban fuzzy sets

Post-suburban fuzzy sets

Tingkat migrasi masuk yang tinggi ${ }^{\mathrm{a}}$

Daya tarik pemandangan yang tinggi ${ }^{\text {a }}$

Aksesibilitas yang baik ${ }^{\mathrm{a}}$

Indeks harga lahan tinggi ${ }^{a}$

Daya beli per kapita tinggi ${ }^{\text {a }}$

Memiliki banyak lulusan akademi dan universitas ${ }^{a}$

Banyak tenaga kerja yang melakukan komuter ke pusat kota $^{a}$

Rata-rata jumlah anggota rumah tangga kecil ${ }^{\text {a }}$

${ }^{a}$ fungsi keanggotaan linier

Sumber: Helbich dan Leitner (2009)

Dalam pembangunan di China, pemerintah telah melakukan fasilitasi pola pertumbuhan perkotaan baik secara langsung maupun tidak langsung. Sektor publik masih memainkan peranan yang kuat dalam pengembangan lahan, namun sektor swasta juga semakin menunjukkan eksistensinya melalui peningkatan pengaruh dalam pengambilan keputusan mengenai pembangunan lahan (Feng et al., 2008 dalam Firman \& Fahmi, 2017). Akibatnya, terjadi pewarisan sebagian kewenangan kepada tingkat yang lebih rendah sehingga berdampak kepada penguatan kapasitas pemerintah daerah. Bentuk suburbanisasi seperti yang terdapat di Beijing dapat dikatakan berada pada tahap awal post-suburbanisasi. Hal ini dikarenakan kawasan suburban Beijing masih belum sepenuhnya terlepas dari keterikatan terhadap inti kota tradisional. Sebagian besar pekerja masih bekerja di pusat kota meskipun banyak perusahaan yang berpindah ke sekelilingnya sehingga menciptakan pola komuter balik. Kondisi ini dapat memperpanjang jarak komuter dan menciptakan kemacetan yang lebih besar (Wu \& Phelps, 2008).

Terjadinya post-suburbanisasi dapat dilihat melalui dua perspektif. Pada perspektif pertama, fenomena tersebut dipicu oleh pembangunan industri melalui model produksi baru seperti kompleks industri (Hise, 2001). Pembangunan kompleks industri di suburban banyak dipengaruhi oleh kekuatan internal termasuk didalamnya perubahan perilaku serta politik dari bentuk interaksi antara pengembang dan pimpinan lokal. Perspektif berikutnya melihat post-sburbanisasi sebagai fenomena yang berkaitan kekuatan eksternal dari globalisasi, dimana persaingan ekonomi secara internasional mengharuskan pilihan lokasi untuk aktivitas ekonomi semakin fleksibel. Dalam hal ini, suburban dipandang sebagai lokasi yang lebih mudah beradaptasi terhadap tren global karena memiliki pola hidup yang relatif lebih modern seperti meningkatnya individualisme, simbolisme, dan konsumerisme (Kling etal., 1995b). Keseru (2013) berpendapat bahwa terdapat beberapa bentuk perkotaan maupun proses yang dapat
Tingkat migrasi masuk yang tinggi ${ }^{\text {a }}$

Daya tarik pemandangan moderat ${ }^{\mathrm{b}}$

Aksesibilitas cukup baik ${ }^{\mathrm{b}}$

Indeks harga lahan rendah a

Daya beli per kapita tinggi moderat ${ }^{\mathrm{b}}$

Tidak banyak lulusan akademi dan universitas ${ }^{b}$

Memiliki banyak lokasi komuter metropolitan ${ }^{a}$

Banyak anggota rumah tangga tunggal atau pasangan ${ }^{\mathrm{a}}$

Tingkat partisipasi tenaga kerja perempuan tinggi ${ }^{\text {a }}$ dipergunakan sebagai indikator pembangunan postsuburban:

a. Suburbanisanisasi atau desentralisasi pekerjaan;

b. Pendekatan polisentris;

c. Pusat suburban baru yang memiliki penggunaan campuran (edge cities);

d. Pusat perusahaan di lokasi suburban;

e. Kota bandar udara;

f. Struktur ekonomi Post-Fordist di kawasan suburban (jasa, industri berteknologi tinggi, serta pusat penelitian dan pengembangan);

g. Berkembangnya pusat hiburan suburban serta fasilitas akomodasi;

h. Arsitektur posmodern;

i. Gated communities;

Dengan demikian dapat disimpulkan bahwa postsuburbanisasi merupakan perubahan posmodern atau reorientasi kembali dalam struktur spasial menuju sesuatu yang baru dan berbeda dibandingkan dengan suburbia yang kita kenal sebelumnya. Perubahan tersebut menekankan tentang proses pematangan struktur suburban, termasuk didalamnya adalah pengayaan fungsi serta reorganisasi spasial yang secara kualitatif mampu memberikan keuntungan bagi suburban dalam berbagai aspek masyarakat posmodern serta pembangunan perkotaan (Helbich \& Leitner, 2009). Proses post-suburbanisasi membentuk morfologi perkotaan dan struktur spasial kawasan di sekitarnya (Helbich, 2012). Namun, post-suburbanisasi tidak selalu merepresentasikan fenomena spasial baru, melainkan dapat juga dilihat sebagai penyesuaian kembali implikasi spasial perkotaan akibat terbentuknya parameter keputusan lokasi yang baru (Lewis, 2001). Bentuk spasial yang dihasilkan tidak selalu menggantikan pusat kota tradisional akan tetapi menjadi pelengkap bagi struktur yang telah ada. Maka jika dibandingkan dengan edge city, istilah "city-edge" (Bontje \& Burdack, 2005) dipandang lebih tepat untuk menggambarkan karakteristik tersebut dalam konteks transformasi pusat suburban di Eropa. 


\section{ARTI KEBERADAAN POST-SUBURBAN}

Upaya untuk dapat mensejalankan pembangunan rangkaian struktur multipusat post-suburban dalam region metropolitan yang lebih berkelanjutan merupakan tantangan bagi perencanaan pada dekade mendatang. Oleh karena itu, identifikasi keberadaan fenomena post-suburbia pada dasarnya ditujukan untuk memahami kemungkinan kontribusi yang dapat diberikan oleh pusat pekerjaan baru di kawasan pinggiran metropolitan pada pembangunan regional yang berkelanjutan. Yaitu apakah konsentrasi pekerjaan baru di kawasan suburban dapat mendukung atau justru kontraproduktif terhadap strategi pembangunan regional yang berkelanjutan (Bontje, 2004). Postsuburbia saat ini dapat dijumpai pada banyak region multipusat berupa koridor pertumbuhan yang dapat berlangsung hingga lebih dari seratus mil jaraknya dari pusat tradisional. Oleh karena itu, suburban merupakan bagian dari kawasan kompleks di pinggiran kota, dimana pekerjaan terdapat bersama-sama dengan permukiman (Fishman, 1996).

Dekonsentrasi ekstrim seperti di Los Angeles seringkali digeneralisir sebagai urban sprawl, yang secara umum dianggap sebagai bentuk pembangunan yang negatif. Terjadinya urban sprawl akan membangkitkan mobilitas, namun dalam proses suburbanisasi berbagai kebutuhan dasar manusia seperti perumahan, pekerjan, pendidikan serta rekreasi semakin terpisah satu sama lain (Keseru, 2013). Bontje (2004) berpendapat bahwa tidak semua proses dekonsentrasi populasi serta pekerjaan dapat digeneralisir sebagai urban sprawl, karena dekonsentrasi akan memiliki bentuk yang berbeda pada lokasi metropolitan yang berbeda. Termasuk didalamnya adalah bentuk yang relatif padu, namun memiliki konsentrasi yang tersebar pada koridor jalan raya atau pada pusat aktivitas baru (Ewing, 1997). Dengan demikian, proses dekonsentrasi tidak selalu harus membawa dampak negatif terhadap pembangunan regional berkelanjutan.

Pada post-suburbia, suburban mengalami perlemahan ikatan dengan pusat kota dan bertransformasi menjadi kota tersendiri yang independen, dimana banyak aktifitas khusus yang menunjang permukiman seperti pusat perbelanjaan, kompleks industri teknologi tinggi, serta fasiltas pendidikan. Dampak semakin terpisahnya lokasi tersebut dengan pusat kota kemudian menjadi kurang begitu dirasakan karena hasil desentralisasi memiliki dinamisme ekonomi dan teknologi sebagaimana yang terdapat di pusat kota (Fishman, 1987). Keberadaan berbagai fasilitas tersebut menjadikan suburban semakin mandiri dan melemahkan kekuatan pemusatan yang dimiliki oleh inti kota tradisional (Fishman, 1996; Soja, 2000). Fenomena ini menghasilkan kawasan suburban dengan beberapa pusat yang semakin mengaburkan perbedaan antara perkotaan dan suburban (Feng et al., 2008 dalam Firman \& Fahmi, 2017).
Karakteristik utama dari struktur post-suburban adalah fragmentasi kawasan metropolitan menjadi daerah permukiman, ekonomi, masyarakat, serta budaya yang semakin independen (Wood, 2003, dalam Helbich \& Leitner, 2009). Akibatnya, model perkotaan monosentris menjadi tidak sesuai dengan realitas di lapangan dan kehilangan kekuatan dalam menjelaskan realitas tersebut (Anas et al., 1998). Borsdorf (2003, dalam Helbich \& Leitner, 2010) berpendapat bahwa pola perkotaan yang terbentuk akibat desentralisasi tidak selalu bersifat homogen, namun struktur yang dihasilkan akan mendekati pola yang terpisah (fraktal). Helbich dan Leitner (2009) berargumen bahwa kondisi ini dapat menyebabkan dampak spasial yang luas yaitu:

a. Pola interaksi suburban melalui perjalanan komuter yang sebagian besar awalnya berlangsung secara radial dari pinggiran menuju inti kota menjadi semakin tidak berlaku. Bentuk interaksi tersebut digantikan oleh perjalanan yang menyebar dan multi arah;

b. Terjadi transformasi permukiman yang semula hanya diperuntukan bagi peristirahatan di malam hari menjadi lokasi untuk perumahan dan pekerjaan. Sementara lingkungan suburban yang semula bersifat homogen berubah menjadi semakin heterogen.

Dampak positif terpenting dari dekonsentasi pekerjaan adalah kemungkinan terjadinya penurunan intensitas permasalahan 'job mismatch' yang muncul seiring dengan proses urbanisasi (Bontje, 2004). Terjadinya relokasi pada berbagai jasa menjadikan strukturpopulasisemakinberagambaiksecarademografi dan sosioekonomi. Akibatnya, pusat kota tradisional kehilangan keunggulan intra-metropolitannya dan menjadi salah satu dari beberapa komponen region perkotaan (Fishman, 1987). Ketergantungan postsuburbia terhadap mobil menyebabkan kurangnya perhatian terhadap fasilitas pejalan kaki (Kling et al., 1995a). Sementara komuter perkotaan yang secara tradisional didominasi oleh pergerakan radial dari dan menuju pusat kota, kini dicirikan dengan pola multiarah serta tujuan yang sulit didefinisikan (Schwanen, 2002).

Dalam hal politik realitas post-suburban telah memunculkan tingkat pragmatisme administratif serta politik dalam hubungan antarpemerintah yang saling terkait dengan permasalahan metropolitan tersebut (Phelps et al., 2010). Para penduduk postsuburbia menciptakan cara hidup dimana institusi seperti pemerintah pusat maupun daerah kurang dapat dirasakan kehadiran serta peranannya sebagiamana yang didapati pada perkotaan tradisional (Kling et al., 1995a). Penghuni post-suburbia memiliki cara pandang oportunis dengan berusaha memaksimalkan kebebasan individu dan membatasi ruang gerak peraturan perencanaan tidak dapat terpenuhi karena pemerintahan desentralisasi tidak memiliki kapasitas institusional untuk merealisasikan aturan perencanaan 
yang telah disetujui (Hudalah et al., 2007). Organisasi spasial post-suburbia merupakan hasil dari kumpulan kordinasi yang kompleks dan lemah pada berbagai keputusan pengusaha swasta serta politisi, yang mencerminkan kepentingannya (Kling et al., 1995b).

\section{POST-SUBURBANISASI DI INDONESIA}

Transformasi pola spasial perkotaan pada metropolitan di Asia memiliki perbedaan dengan Eropa maupun Amerika. Pembangunan perkotaan di Asia banyak dihubungkan dengan region metropolitan yang luas dan memiliki karakteristik aktivitas ekonomi serta penggunaan lahan permukiman yang beragam di pinggiran kota besar (Firman, 2009). Di Indonesia, proses transformasi perkotaan pada awalnya terjadi di kota-kota besar seperti Jakarta, Surabaya, Medan, Bandung dan lain-lain. Selama ini, berbagai riset mengenai transformasi perkotaan di Indonesia lebih banyak dipusatkan di Jakarta Metropolitan Area (JMA). JMA merupakan wilayah adminsitratif dari kawasan urban di Jakarta dan wilayah sekelilingnya.

Fungsi region ini sangat penting karena menjadi pusat sosial, politik, budaya dan ekonomi di Indonesia. Kedudukan JMA bukan hanya sebagai suatu sistem fungsional mega-urban (Rustiadi et al., 2015), namun juga merupakan region kota yang didominasi oleh Jakarta sebagai mega kota (Laquian, 2011). Dengan luas $6.392 \mathrm{~km}^{2}$, populasi JMA pada tahun 2015 diperkirakan telah mencapai 30,97 juta jiwa sehingga membuatnya tidak hanya menjadi kawasan metropolitan terbesar di Indonesia, melainkan juga menjadi yang terbesar kedua di Asia. Dari segi ekonomi, pada tahun 2010 JMA tercatat memberikan kontribusi sebesar 25 persen dari PDB Indonesia (Rustiadi et al., 2015). Sebagai pusat pemerintahan Indonesia, Jakarta memainkan peranan utama dalam menjaga kestabilan nasional. Daerah ini juga memiliki karakteristik kosmopolitan karena menjadi pusat budaya serta pendidikan.

Hudalah et al. (2013) menyatakan bahwa kunci dari proses urbanisasi yang terjadi di JMA adalah pembangunan kawasan industri. Transformasi perkotaan JMA didorong oleh ekspansi ekonomi dalam bentuk kompleks industri serta kota satelit baru yang menghasilkan kawasan periurban yang memiliki guna lahan campuran (Rustiadi \& Panuju, 2002). Proses dekonsentrasi industri dari inti JMA menuju kawasan suburban tidak hanya terjadi pada industri besar (Hudalah \& Firman, 2012) melainkan juga industri kecil (Ansar \& Hudalah, 2013). Tingginya kebutuhan terhadap lahan kemudian mendorong pengembang privat untuk melakukan praktek land banking sehingga menyebabkan pembangunan menjadi tidak terkendali (Winarso, 2011). Desentralisasi populasi dan aktivitas ekonomi kemudian menjadi semakin meluas menuju kawasan peri urban, bahkan lebih jauh mencapai zona desakota sehingga membentuk daerah metropolitan tambahan atau kota mega region (Robinson, 1995). Pembangunan JMA telah bergeser menuju kawasan pinggiran di sekelilingnya (Ansar \& Hudalah, 2013; Firman, 2009, 2011; Firman \& Fahmi, 2017; Hudalah \& Firman, 2012; Hudalah et al., 2013; Winarso et al., 2015).

Dinamika pembangunan perkotaan di JMA sangat dipengaruhi oleh kebijakan pembangunan yang terus berubah, namun memiliki kesamaan dalam hal kurangnya peran pemerintah. Rukmana (2015) berargumen bahwa selama rezim orde baru (1966-1997) pembangunan JMA ditandai oleh absennya perencanaan serta peraturan. Pendekatan ekonomi liberal dalam kebijakan yang diterapkan telah melahirkan dualitas bentuk perkotaan, yaitu terencana dan tidak terencana (Winarso, 2011). Pasca rezim orde baru, pembangunan JMA ditandai dengan eforia desentralisasi yang mendorong terjadinya fragmentasi serta konflik lahan (Firman \& Fahmi, 2017). Saat ini di JMA terdapat 13 wilayah administratif setingkat kota yang berada dibawah tiga provinsi berbeda. Keberadaan Badan Kerjasama Pembangunan (BKSP) yang dibentuk sejak tahun 1975 sebagai lembaga koordinasi menjadi tidak efektif karena masing-masing pemerintaha memiliki kewenangan yang hampir setara. Kelemahan institusi pemerintahan tersebut menyebabkan pembangunan lahan banyak dikendalikan oleh sektor privat (Firman, 2004; Hudalah et al., 2013; Winarso et al., 2015). Sebagai dampaknya, pembangunan di daerah periurban mengalami segregasi spasial dan pekerjaan (Winarso et al., 2015) sehingga mendorong JMA untuk memasuki fase awal dari post-suburbia (Firman \& Fahmi, 2017).

Post-suburbanisasi di Asia nampaknya merupakan suatu kelanjutan dari pola investasi sektor swasta. Peranan sektor swasta sangat penting dalam proses suburbanisasi pada banyak negara asia melalui investasi pembangunan industri, perdagangan, dan permukiman real estate di kawasan suburban (Firman, 2009). Dalam hal ini, berbagai elemen dari sektor swasta diasumsikan telah memiliki kekuatan yang signifikan dalam mengembangkan lahan serta serta mengelola keputusan (Shatkin, 2008). Terjadinya konversi lahan secara masif, munculnya gated communities, dan pembangunan kota baru di pinggiran metropolitan Jakarta merupakan hasil dari kebijakan deregulasi serta debirokratisasi yang dilakukan oleh pemerintah sejak periode 1980an (Firman, 2004; Hudalah et al., 2007; Winarso \& Firman, 2002). Kota baru yang dibangun tersebut pada dasarnya memang direncanakan sebagai kota yang mandiri lengkap dengan berbagai fasilitas perkotaan serta pusat pekerjaannya sendiri.

Keberadaan elemen post-suburban dalam perkembangan metropolitan di Indonesia pertama kali teridentifikasi di kawasan JMA oleh Firman (2011). Berbagai elemen tersebut antara lain pertumbuhan permukiman di kawasan pinggiran, perubahan guna lahan dari pertanian menjadi lahan terbangun untuk berbagai kebutuhan perumahan dan ekonomi, serta munculnya pola komuter balik dari Jakarta menuju pinggiran. Sebagaimana di China, post-suburbanisasi 
di Jabodetabek secara fisik memiliki karakteristik pola campuran antara perumahan tradisional serta pembangunan perumahan baru. Hal ini muncul sebagai dampak dari kebijakan pemerintah pusat yang berupaya menarik aliran penanaman modal asing (FDI) sebesar-besarnya. Namun bentuk post-suburbanisasi di Jabodetabek sepertinya tidak dapat menyerupai bentuk di negara barat. Sebagian penyebabnya adalah karena banyak orang yang memutuskan untuk tinggal di pusat kota dan melakukan komuter ke daerah suburban untuk bekerja maupun melakukan aktivitas lainnya. Pola ini sangat berkaitan dengan meningkatnya peran sektor swasta akibat kebijakan pemerintah yang mengizinkan privatisasi pengembangan lahan (Firman \& Fahmi, 2017).

Pada tahap awal, transformasi suburban di JMA dapat dipandang sebagai implikasi spasial restrukturisasi ekonomi pertanian menuju kepada sektor manufaktur. Sejalan dengan waktu, integrasi perekonomian wilayah dengan kapitalisme global menyebabkan dominasi sektor manufaktur mulai tergantikan oleh sektor jasa. Namun kemunculan fenomena post-suburbia tidak hanya terjadi akibat globalisasi serta proses politik berupa desentralisasi pemerintahan, melainkan juga terkit dengan konteks daya dukung wilayah. Wilayah inti metropolitan Jakarta yang menjadi pusat pertumbuhan telah mencapai titik jenuh dan sulit bersaing untuk menarik FDI. Kemunculan post-suburbia tidak sepenuhnya merupakan hasil desain dari pemerintah dan tidak sepenuhnya dapat berimprovisasi dengan baik (Hudalah \& Firman, 2012). Hal ini menunjukkan bahwa transformasi post-suburban di JMA lebih disebabkan oleh adanya peluang dibandingkan dengan hasil kreatifitas dan perencanaan.

\section{TANTANGAN PEMBANGUNAN DI POST- SUBURBAN}

Transformasi perkotaan merupakan perubahan yang berlangsung dari waktu ke waktu, sehingga pemahaman mengenai pembangunan yang terjadi saat ini memerlukan adanya pengetahuan dari proses pertumbuhan dan pembangunan perkotaan sebelumnya. (Thorns, 2002, p. 2). Namun demikian, konsep dalam mengidentifikasi pertumbuhan perkotaan tersebut hingga saat ini masih menjadi perdebatan. Reis et al. (2016) berargumen bahwa setidaknya terdapat tiga konsep pertumbuhan kota yang berbeda dan dipergunakan secara luas dalam literatur perencanaan regional, yaitu perubahan populasi, performa ekonomi, serta perluasan spasial kawasan perkotaan. Selama ini riset yang sudah dilakukan masih terfokus pada rumusan mengenai apa itu post-suburbia, bagaimana proses terjadinya, serta bagaimana keterkaitan antar elemen didalamnya. Namun bagaimana dampak fenomena post-suburbia masih belum banyak diteliti. Seiring dengan kemunculan fenomena post-suburbia, maka terdapat beberapa kritik serta perdebatan yang mengiringi perkembangan konsep serta teori postsuburbia.
Pertama, sebagai fenomena global, keberadaan post-suburban dapat ditemukan pada berbagai lokasi meskipun dengan skala dan cara yang berbeda (Soja, 2000). Dalam banyak kasus, identitas lokasi post-suburban sangat berkaitan dengan aktivitas ekonomi di tempat tersebut (Borsdorf, 2004). Namun dalam konteks geografi, terdapat kesulitan dalam menempatkan tampilan, bentuk, serta morfologi post-suburbia. Perbedaan antara suburbia dan postsuburbia masih belum terlalu jelas, dan situasi tersebut memiliki dampak penting terhadap aspek politik. Adanya perbedaan bentuk dan morfologi permukiman baru pada lokasi negara yang berbeda menyebabkan ketidakpastian dalam mendapatkan titik temu yang dapat digunakan sebagai perbandingan (Phelps et al, 2006a). Oleh karena itu, pertanyaan mengenai aspek geografis dari post-suburbia akan tetap menjadi hal yang sangat penting (Phelps et al., 2010).

Kedua, meskipun konsep dan teori perubahan spasial dari suburbia menjadi post-suburbia telah cukup mapan, tetapi bukti empiris mengenai perubahan secara spasial sejauh ini dirasakan masih sangat kurang (Helbich \& Leitner, 2009). Merujuk kepada teori tahapan transformasi perkotaan dari Phelps dan Wu (2011b) masih tersisa tahap ketiga transformasi perkotaan selepas post-suburbanisasi. Namun demikian, apa yang terjadi selepas tercapainya post-suburbia tersebut masih merupakan suatu asumsi. Upaya untuk menemukan bukti untuk struktur perkotaan di luar pola urban ini masih sangat kurang. Adanya perbedaan dalam pola transformasi antar lokasi kemudian memunculkan pertanyaan mengenai pola yang akan muncul dari lima kemungkinan yang ada. Apakah post-suburbanisasi merupakan fase transisi yang mengarah pada bentuk intra metropolitan yang terpencar (Shearmur et al., 2007), atau mengarah kepada pola polisentris dengan serangkaian kota baru didalamnya.. Untuk itu, investigasi lanjutan mengenai stuktur dan morfologi perkotaan akan sangat diperlukan.

Ketiga, hingga saat ini masih belum begitu jelas apakah perpindahan pekerjaan ke kawasan pinggiran lebih disebabkan oleh efek kejenuhan pusat kota atau lebih kepada faktor independen. Dalam konteks Eropa, terdapat kemungkinan bahwa kedua faktor tersebut bekerja dengan bobot yang berbeda pada region yang berbeda. Pada kenyataannya, kebijakan dekonsentrasi pembangunan yang dilakukan tidak selalu memberikan dampak postif. Sejak tahun 1960 hingga pertengahan 1980, kebijakan perencanaan spasial Belanda berupa 'concentrated deconcentration' telah mendukung pembangunan pusat pertumbuhan disekitar kota besar. Pusat pertumbuhan tersebut pada dasarnya ditujukan untuk menyediakan kawasan perumahan suburban bagi mereka yang ingin keluar dari kota besar. Kebijakan tersebut berupaya mencegah terjadinya urban sprawl dengan cara mengumpulkan pembangunan perumahan suburban pada lokasi yang jumlahnya terbatas. Pusat pertumbuhan yang memiliki letak paling jauh dari 
kota besar memiliki fungsi tambahan yaitu untuk membangun pusat ekonomi dari kawasan perkotaan baru yang independen, dan mendorong pertumbuhan ekonomi di kawasan pinggiran yang tertinggal. Namun dalam kenyataannya, lokasi pekerjaan yang baru justru memiliki karakteristik sebagai berikut (Bontje, 2004):

a. Mengambil lokasi yang relatif dekat dari batas kota dan suburban yang terdekat dari batas kota. Akibatnya, pusat pertumbuhan baru justru berada dekat dari kota besar pada lokasi yang semula hanya ditujukan bagi penyediaan permukiman suburban serta pelayanan yang diperlukan;

b. Kesempatan bagi penduduk suburban untuk menemukan pekerjaan di dekat rumahnya hanya didapati oleh pekerja dengan keahlian tinggi. Jenis pekerja ini banyak terdapat pada kawasan suburban. Sementara itu, pekerja dengan keahlian rendah yang banyak tinggal di pusat kota sulit untuk menemukan pekerjaan di suburban. Jenis pekerja ini umumnya memiliki toleransi komuter yang lebih rendah dibandingkan dengan pekerja berkeahlian tinggi, sehingga dekonsentrasi pekerjaan yang berkelanjutan dapat mengancam akses mereka terhadap pekerjaan;

c. Sebagian besar lokasi pekerjaan baru yang dibangun dalam beberapa periode terakhir mengambil lokasi yang dekat dengan jalan raya, sehingga terdapat kecenderungan untuk meningkatkan penggunaan mobil sebagai moda transportasi.

Adanya fakta tersebut memunculkan pertanyaan mengenai dampak transformasi setelah post-suburban terhadap bentuk keseimbangan rumah dan pekerjaan serta pola komuter yang dihasilkan. Karena pola komuter ditentukan oleh keseimbangan antara pekerjaan dengan lokasi rumah, maka hal ini akan sangat dipengaruhi oleh proses suburbanisasi permukiman dan pekerjaan (Keseru, 2013). Pada struktur yang hanya mengalami suburbanisasi permukiman dan populasi (monosentris), pola komuter yang terjadi adalah pola tradisional, yaitu dari suburban menuju pusat dan sirkulasi perjalanan di dalam pusat kota (self containment). Namun ketika pekerjaan turut mengalami desentralisasi, maka terdapat peningkatan intensitas komuter balik (reversecommuting) dan komuter silang (cross-commuting) sebagai indikasi pembangunan polisentris (van der Laan, 1998). Keseru (2013) berargumen bahwa aspek khusus dari post-suburbanisasi seperti hubungan antara post-suburbanisasi dengan komuter belum banyak dieksplorasi. Aspek ini perlu mendapatkan perhatian lebih besar dalam riset terkait post-suburban kedepannya.

\section{DAFTAR PUSTAKA}

Anas, A., Arnott, R., \& Small, K. A. (1998). Urban spatial structure. Journal of Economic Literature, 36(3), 1426-1464.
Ansar, Z., \& Hudalah, D. (2013). Dekonsentrasi Industri Kecil Di Metropolitan Jabodetabek. Jurnal Perencanaan Wilayah Dan Kota, 2(3), 687-700.

Bontje, M. (2004). From suburbia to post-suburbia in the Netherlands: Potentials and threats for sustainable regional development. Journal of Housing and the Built Environment, 19(1), 25-47.

Bontje, M., \& Burdack, J. (2005). Edge Cities, Europeanstyle: Examples from Paris and the Randstad. Cities, 22(4), 317-330.

Borsdorf, A. (2004). On the way to post-suburbia? Changing structures in the outskirts of European cities. In A. Borsdorf \& P. Zembri (Eds.), European Cities Structures: Insights on Outskirts (pp. 7-30).

Dear, M., \& Dahmann, N. (2008). Urban Politics and the Los Angeles School of Urbanism. Urban Affairs Review, 44(2), 266-279.

Ewing, R. (1997). Is Los Angeles-Style Sprawl Desirable? Journal of the American Planning Association, 63(1), $107-126$.

Firman, T. (2004). Major issues in Indonesia's urban land development. Land Use Policy, 21(4), 347355.

Firman, T. (2009). The continuity and change in megaurbanization in Indonesia: A survey of JakartaBandung Region (JBR) development. Habitat International, 33(4), 327-339.

Firman, T. (2011). Post-suburban Elements in an Asian Extended Metropolitan Region: The Case of Jabodetabek (Jakarta Metropolitan Area). In N. A. Phelps \& F. Wu (Eds.), International Perspectives on Suburbanization: A Post-Suburban World? (pp. 195-209). London: Palgrave Macmillan UK.

Firman, T., \& Fahmi, F. Z. (2017). The Privatization of Metropolitan Jakarta's (Jabodetabek) Urban Fringes: The Early Stages of "Post-Suburbanization" in Indonesia. Journal of the American Planning Association, 83(1), 68-79.

Fishman, R. (1987). Bourgeois Utopias: The Rise and Fall of Suburbia. Basic Books.

Fishman, R. (1996). Bourgeois utopias: visions of suburbia. In S. S. Fainstein \& S. Campbell (Eds.), Readings in urban theory (pp. 23-60). Oxford, UK: Blackwell.

Glaeser, E. L., \& Kahn, M. E. (2004). Sprawl and Urban Growth. In J. Vernon Henderson and JacquesFrançois Thisse (Ed.), Handbook of Regional and Urban Economics (Vol. Volume 4, pp. 2481-2527). Elsevier.

Golubchikov, O., Phelps, N., \& Makhrova, A. (2010). Post-suburbia: Growth machine and the emergence of "edge city" in the metropolitan context of Moscow. Geography, Environment, Sustainability, 3(1), 44-55.

Harris, R., \& Larkham, P. (1999). Suburban foundation, form and function. In P. Larkham \& R. Harris (Eds.), Changing Suburbs (pp. 1-31). New York: Routledge. 
Helbich, M. (2012). Beyond Post-suburbia? Multifunctional Service Agglomeration in Vienna's Urban Fringe: Multifunctional Service Agglomeration In Vienna's Urban Fringe. Tijdschrift Voor Economische En Sociale Geografie, 103(1), 39-52.

Helbich, M., \& Leitner, M. (2009). Spatial Analysis of the Urban-to-Rural Migration Determinants in the Viennese Metropolitan Area. A Transition from Suburbia to Post-suburbia? Applied Spatial Analysis and Policy, 2(3), 237-260.

Helbich, M., \& Leitner, M. (2010). Post-suburban Spatial Evolution of Vienna's Urban Fringe: Evidence from Point Process Modeling. Urban Geography, 31(8), 1100-1117.

Hudalah, D., \& Firman, T. (2012). Beyond property: Industrialestatesand post-suburban transformation in Jakarta Metropolitan Region. Cities, 29(1), 4048.

Hudalah, D., Viantari, D., Firman, T., \& Woltjer, J. (2013). Industrial Land Development and Manufacturing Deconcentration in Greater Jakarta. Urban Geography, 34(7), 950-971.

Hudalah, D., Winarso, H., \& Woltjer, J. (2007). Periurbanisation in East Asia: A new challenge for planning? International Development Planning Review, 29(4), 503-519.

Keseru, I. (2013). Post-suburban transformation in the functional urban region of Budapest in the context of changing commuting patterns ( $\mathrm{PhD}$ Thesis). University of Szeged, Szeged.

Kling, R., Olin, S. C., \& Poster, M. (1995a). Beyond the Edge: The Dynamism of Post-suburban Regions. In R. Kling, S. C. Olin, \& M. Poster (Eds.), Postsuburban California: The Transformation of Orange County since World War II (paperback edition). University of California Press.

Kling, R., Olin, S. C., \& Poster, M. (1995b). The Emergence of Post-suburbia: An Introduction. In R. Kling, S. C. Olin, \& M. Poster (Eds.), Postsuburban California: The Transformation of Orange County since World War II (paperback edition). University of California Press.

Lang, R., LeFurgy, J., \& Nelson, A. C. (2006). The six suburban eras of the United States. Opolis, 2(1), 65-72.

Laquian, A. A. (2011). The planning and governance of Asia's mega-urban regions. Population Distribution, Urbanization, Internal Migration and Development: An International Perspective, United Nations Department of Economic and Social Affairs, Population Division, New York: United Nations, 302-322.

Lee, B. (2007). "Edge” or "edgeless" cities? Urban spatial structure in US metropolitan areas, 1980 to 2000. Journal of Regional Science, 47(3), 479-515.

Lewis, R. D. (2001). A city transformed: manufacturing districts and suburban growth in Montreal, 1850-
1929. Journal of Historical Geography, 27(1), 20-35.

Lucy, W. H., \& Phillips, D. L. (1997). The post-suburban era comes to Richmond: city decline, suburban transition, and exurban growth. Landscape and Urban Planning, 36(4), 259-275.

McGee, T. G. (1991). The Emergence of Desakota regions in Asia. In N. S. Ginsburg, B. Koppel, \& T. G. McGee (Eds.), The Extended Metropolis: Settlement Transition Is Asia. Honolulu: University of Hawaii Press.

Phelps, N. A., Wood, A. M., \& Valler, D. C. (2010). A Post-suburban World? An Outline of a Research Agenda. Environment and Planning A, 42(2), 366383.

Phelps, N. A., \& Wu, F. (2011a). Conclusion: Postsuburban Worlds? In N. A. Phelps \& F. Wu (Eds.), International Perspectives on Suburbanization: A Post-Suburban World? (pp. 245-257). London: Palgrave Macmillan UK.

Phelps, N. A., \& Wu, F. (2011b). Introduction: International Perspectives on Suburbanization: A Post-suburban World? In N. A. Phelps \& F. Wu (Eds.), International Perspectives on Suburbanization: A Post-Suburban World? (pp. 1-14). London: Palgrave Macmillan UK.

Reis, J. P., Silva, E. A., \& Pinho, P. (2016). Spatial metrics to study urban patterns in growing and shrinking cities. Urban Geography, 37(2), 246-271.

Robinson, I. M. (1995). Emerging spatial patterns in ASEAN mega-urban regions: Alternative strategies. In Mega Urban Regions of Southeast Asia (pp. 78108). Vancouver: UBC Press.

Rukmana, D. (2015). The Change and Transformation of Indonesian Spatial Planning after Suharto's New Order Regime: The Case of the Jakarta Metropolitan Area. International Planning Studies, 20(4), 350-370.

Rustiadi, E., \& Panuju, D. R. (2002). Spatial Pattern of Suburbanization and Land Use Change Process: Case Study in Jakarta Suburb. In Y. Himiyama, M. Hwang, \& T. Ichinose (Eds.), Land-use Changes in Comparative Perspective. Enfield (NH): Science Publishers, Inc.

Rustiadi, E., Pribadi, D. O., Pravitasari, A. E., Indraprahasta, G. S., \& Iman, L. S. (2015). Jabodetabek Megacity: From City Development Toward Urban Complex Management System. In R. B. Singh (Ed.), Urban Development Challenges, Risks and Resilience in Asian Mega Cities (pp. 421445). Tokyo: Springer Japan.

Schwanen, T. (2002). Urban Form and Commuting Behaviour: A Cross-European Perspective. Tijdschrift Voor Economische En Sociale Geografie, 93(3), 336-343.

Shatkin, G. (2008). The City and the Bottom Line: Urban Megaprojects and the Privatization of Planning in Southeast Asia. Environment and Planning A, 40(2), 383-401. 
Shearmur, R., Apparicio, P., Lizion, P., \& Polese, M. (2007). Space, Time, and Local Employment Growth: An Application of Spatial Regression Analysis. Growth and Change, 38(4), 696-722.

Soja, E. W. (2000). Postmetropolis: Critical Studies of Cities and Regions. Wiley.

Thorns, D. C. (2002). The Transformation of Cities: Urban Theory and Urban Life. New York: Palgrave Macmillan.

van der Laan, L. (1998). Changing Urban Systems: An Empirical Analysis at Two Spatial Levels. Regional Studies, 32(3), 235-247.

Winarso, H. (2011). Urban dualism in the Jakarta metropolitan area. In Megacities (pp. 163-191). Springer.

Winarso, H., \& Firman, T. (2002). Residential land development in Jabotabek, Indonesia: triggering economic crisis? Habitat International, 26, 487506.

Winarso, H., Hudalah, D., \& Firman, T. (2015). Periurban transformation in the Jakarta metropolitan area. Habitat International, 49, 221-229.

Wu, F., \& Phelps, N. A. (2008). From suburbia to postsuburbia in China? Aspects of the transformation of the Beijing and Shanghai global city regions. Built Environment, 34(4), 464-481. 